\title{
Induced Systemic Resistance and the Rhizosphere Microbiome
}

\author{
Peter A.H.M. Bakker ${ }^{1 *}$, Rogier F. Doornbos ${ }^{1 \#}$, Christos Zamioudis ${ }^{1}$, Roeland L. Berendsen ${ }^{1}$ and \\ Corné M.J. Pieterse ${ }^{1,2}$ \\ ${ }^{\text {I} P l a n t-M i c r o b e}$ Interactions, Department of Biology, Faculty of Science, Utrecht University, Padualaan 8, 3584 CH Utrecht, the \\ Netherlands \\ ${ }^{2}$ Centre for BioSystems Genomics, P.O. Box 98, 6700 AB Wageningen, the Netherlands \\ ${ }^{\#}$ Current address: Ceradis BV, P.O. Box 376, 6700 AJ Wageningen, the Netherlands
}

(Received on July 23, 2012; Accepted on August 22, 2012)

\begin{abstract}
Microbial communities that are associated with plant roots are highly diverse and harbor tens of thousands of species. This so-called microbiome controls plant health through several mechanisms including the suppression of infectious diseases, which is especially prominent in disease suppressive soils. The mechanisms implicated in disease suppression include competition for nutrients, antibiosis, and induced systemic resistance (ISR). For many biological control agents ISR has been recognized as the mechanism that at least partly explains disease suppression. Implications of ISR on recruitment and functioning of the rhizosphere microbiome are discussed.
\end{abstract}

Keywords : disease suppressive soils, plant pathogens, Pseudomonas spp.

\section{The rhizosphere microbiome}

Plant roots growing in the dark realms of soils are certainly not solitary. They sustain a community of organisms that includes trillions of microbial cells belonging to tens of thousands of species. In this respect plants and animals are actually quite alike, as also animals live in close association with complex microbial communities. The human gut microflora is estimated to consist of $10^{14}$ bacterial cells, ten times more than there are human cells in a body, and belonging to several thousands of species (Arumugam et al., 2011). These microorganisms in the gut play a role in nutrient uptake (Derrien et al., 2010) and obesity (Turnbaugh et al., 2006, 2009), absorption of herbal medicine (Crow, 2011), control of gastrointestinal pathogens (Khoruts et al., 2010), immunity against diseases (Fagundes et al., 2012), and they even are suggested to influence mammal behaviour (Diaz Heijtz et al., 2011; Grenham et al., 2011; Williams et

\footnotetext{
*Corresponding author.

Phone) +31 302536861

E-mail) P.A.H.M.Bakker@uu.nl
}

al., 2012). The collective microbiome in the plant rhizosphere is similarly important for the functioning and health of plants. Uptake of nutrients for a large part depends on microorganisms. Not only are plants directly assisted in their phosphate (Khan et al., 2009; Van der Heijden et al., 2006) and nitrogen uptake (Kraiser et al., 2011) by microoganisms, but many fungal, bacterial and archaeal taxa are also important for nutrient cycling in soil (Van der Heijden et al., 2008). Furthermore, rhizosphere microorganisms support plants through direct control of diseases and their impact on the disease defensive capacity of plants (Bakker et al., 2007, Berendsen et al., 2012) and on tolerance to abiotic stresses (Yang et al., 2008). The importance of the rhizosphere microflora for plant growth and health has been studied for decades. Rhizodeposition of carbon compounds increases microbial activity and biomass in rhizosphere soil (Hartmann et al., 2009), and interactions between members of the microbial rhizosphere community are important drivers of plant growth (Raaijmakers et al., 2009). Compared to the human gut microbiome, the microbiome associated with the plant root is staggeringly complex (Berendsen et al., 2012). Around 3000 culturable soil fungi have been described (Gams, 2007), but this number will undoubtedly increase with the application of molecular techniques (Anderson and Cairney, 2004). In sugar beet rhizosphere soil over 33,000 bacterial and archaeal operational taxonomic units (OTUs) were detected (Mendes et al., 2011). Such a microbial diversity extends the functional repertoire of the plant and its associated microbes beyond imagination. The function that we focus on in this minireview is the ability of specific root associated microorganisms to elicit induced systemic resistance against pathogens.

\section{Disease suppressive soils}

According to the definition by Baker and Cook (1974) disease suppressive soils are "soils in which the pathogen 
does not establish or persist, establishes but causes little or no damage, or establishes and causes disease for a while but thereafter the disease is less important, although the pathogen may persist in the soil." Biological factors have been identified as the most important element in disease suppression in such soils (Mazzola, 2002). A prominent example of disease suppressiveness is take-all decline (TAD). When wheat is grown continuously in the same field, take-all disease caused by Gaeumannomyces graminis var. tritici will develop over the years. However, after a severe outbreak of take-all, the soil becomes suppressive against the disease (Weller et al., 2002). This suppressiveness can be negated by heat treatment and it is transferrable to a conducive soil by mixing a small ratio of suppressive to the conducive soil (Raaijmakers and Weller, 1998). Whereas build up of 2,4-diacetylphloroglucinol producing Pseudomonas fluorescens populations appears to be solely responsible for take-all decline (Raaijmakers and Weller, 1998), 16S rRNA-based techniques have identified additional bacterial taxa that may be involved in take-all decline (Sanguin et al., 2009; Schreiner et al., 2010). Other well examined examples of disease suppressive soils include Fusarium wilt suppressiveness (Alabouvette, 1999), tobacco black root rot disease suppressiveness (Kyselkova et al., 2009), and Rhizoctonia solani suppressiveness (Mendes et al., 2011). In soil naturally suppressive to Fusarium wilt, a synergistic effect of competition for carbon by non-pathogenic Fusarium oxysporum and production of redox-active phenazines appears to play an important role in suppressiveness (Mazurier et al., 2009). Using a 16S rRNA taxonomic microarray several bacterial taxa, including Pseudomonas, Azospirillum, Gluconacetobacter, Bulkholderia, Comamonas and Sphingomonadaceae, were shown to be more prevalent in tobacco black root rot suppressive soil than in conducive soil (Kyselkova et al., 2009). This suggests that suppression of Thielaviopsis basicola in this soil is based on a microbial consortium. Similar findings have been described for a potato common scab suppressive soil (Rosenzweig et al., 2012). An in depth study of the rhizosphere microbiome of the $R$. solani suppressive soil also revealed that a consortium of microbes governs disease suppression. Using PhyloChip analysis, which allows simultaneous detection of $\sim 60,000$ bacterial and archaeal OTUs, 17 taxa belonging to the $\beta$-proteobacteria, $\gamma$-proteobacteria, and the firmicutes were identified as being closely associated with disease suppressiveness (Mendes et al., 2011). The group of Pseudomonaceae has been suggested as a player in disease suppressiveness in all aforementioned disease suppressive soils. Control of diseases by these fluorescent pseudomonads has been studied in detail over the last three to four decades (Weller, 2007). The main modes of action of disease suppression by fluorescent
Pseudomonas spp. are siderophore mediated competition for iron (Duijff et al., 1999), antibiosis (Raaijmakers et al., 2002), and induced systemic resistance (ISR) (Bakker et al., 2007). During the last two decades the involvement of ISR has been recognized as an important and effective mode of action for a range of bacterial and fungal biological control agents.

\section{ISR eliciting biocontrol agents and ISR eliciting deter- minants}

In the early nineties, plant growth promoting rhizobacteria were studied for their abilities to elicit ISR, with special focus on Pseudomonas spp.. It was discovered that when certain biocontrol pseudomonads were applied and kept spatially separated from the pathogen, they still reduced disease, suggesting that the mode of action must be plant mediated (Van Peer et al., 1991; Wei et al., 1991). Induced resistance is a state of enhanced defensive capacity developed by a plant when appropriately stimulated (Van Loon et al., 1998). There is a long and growing list of both biotic and abiotic agents that can protect crops against pathogens by eliciting ISR (Da Rocha and Hammerschmidt, 2005; Reglinski and Walters, 2009). Many bacterial biocontrol agents have been implicated to elicit ISR (De Vleesschauwer and Höfte, 2009), including Bacillus spp. (Jourdan et al., 2009; Kloepper et al., 2004), Pseudomonas spp. (Bakker et al., 2007), and Serratia spp. (Press et al., 1997; Schuhegger et al., 2006). Fungal biocontrol agents reported to elicit ISR include Trichoderma spp. (Koike et al., 2001; Segarra et al., 2009), Piriformospora indica (Shoresh et al., 2010), Penicillium simplicissimum (Elsharkawy et al., 2012), Phoma sp. (Sultana et al., 2009), non-pathogenic Fusarium oxysporum (Fravel et al., 2003), and arbuscular mycorrhizal fungi (Pozo et al., 2009). The above mentioned list of examples of ISR eliciting microorganisms is certainly not exhaustive and one may wonder if there are biological control agents that can not elicit ISR.

Also for microbial determinants that are involved in ISR the list is growing. The first reports on bacterial determinants involved in ISR concerned $P$. fluorescens lipopolysaccharides (Leeman et al., 1995a; Van Peer et al., 1992) and siderophores (Maurhofer et al., 1994). Many more ISR elicitors have been identified by application of purified compounds and the use of mutants that lack the production of a possible eliciting compound (Bakker et al., 2003; De Vleesschauwer and Höfte, 2009). ISR elicitors that were identified using such strategies include flagella (Meziane et al., 2005), iron-regulated metabolites (Audenaert et al., 2002; De Vleesschauwer et al., 2008; Meziane et al., 2005; Ongena et al., 2005; Ran et al., 2005), the antibiotics 2,4-diacetylphloroglucinol (Iavicoli et al., 2003; Weller et 
al., 2012) and pyocyanin (Audenaert et al., 2002; De Vleesschauwer et al., 2006), biosurfactants (Ongena et al., 2007; Tran et al., 2007), and volatile organic compounds (Ryu et al., 2004). Moreover, redundancy of ISR elicitors in a single biological control microorganism has been reported (Bakker et al., 2003; De Vleesschauwer and Höfte, 2009). Taking into account the high population densities of microorganisms in the rhizosphere (Katznelson et al., 1948) and the high diversity of these microbial communities (Mendes et al., 2011), on top of the many microorganisms that have the potential to elicit ISR and the variety in ISR eliciting determinants, it seems reasonable to assume that most plants are in the state of ISR. However, under field conditions ISR can effectively suppress disease (Leeman et al., 1995b, Wei et al., 1996), suggesting that untreated plants are not in the state of ISR.

\section{Why are not all plants in the state of ISR?}

The rhizosphere microflora contains an incredible number of bacterial species (Mendes et al., 2011), and within one species different genotypes are present, as described for Pseudomonas spp. (Glandorf et al., 1993, 1994; Lemanceau et al., 1995). To effectively elicit ISR high population densities of a specific biocontrol strain are introduced into the soil or rhizosphere, usually around $10^{7}$ colony forming units (cfu) per gram of root, see for example Van Pelt et al. (2008). Dose response studies for biological control agents revealed that high populations are needed for effective control of diseases (Bull et al., 1991; Johnson and DiLeone, 1999; Montesinos and Bonaterra, 1996; Raaijmakers and Weller, 1998). Typically bacterial population densities of at least $10^{5} \mathrm{cfu}$ per gram of root are required for control of diseases by fluorescent pseudomonads, either mediated by antibiosis (Raaijmakers and Weller, 1998), or by ISR (Raaijmakers et al., 1995). It seems unlikely that such high population densities of a specific bacterial genotype are present in the rhizospheres of plants in the field, although it has been reported for disease suppressive soils. In take-all decline soil, 2,4-diacetylphloroglucinol producing fluorescent Pseudomonas spp. were detected at densities above the threshold level of $10^{5}$ per gram (De Souza et al., 2003; Raaijmakers and Weller, 1998). Even if one specific bacterial genotype would reach population densities above this threshold, there is specificity in ISR both on the bacterial side and the plant side (Van Loon and Bakker, 2005).

\section{What's in it for the eliciting bacteria?}

Stimulation of ISR eliciting bacteria by plants under pathogen attack was reported by Rudrappa et al. (2008). The roots of $A$. thaliana plants infected by $P$. syringae pv. tomato secreted elevated levels of malic acid, and in a dose dependent manner malic acid stimulated binding to and biofilm formation on the roots by the ISR eliciting Bacillus subtilis strain FB17. In this situation the plant offers a more hospitable rhizosphere environment to the bacteria and in return the plant benefits from protection offered by the bacteria. Rhizobacteria-mediated ISR affects activity and growth of pathogenic microorganisms and may also affect the growth and activity of the indigenous rhizosphere microflora and introduced biological control agents. ISR eliciting microbes may modulate defense responses of the plant to their own benefit (Zamioudis and Pieterse, 2012). In this context it is interesting that in the rhizosphere of Arabidopsis mutant myb72, that can not express Pseudomonas- or Trichoderma-mediated ISR (Segarra et al., 2009; Van der Ent et al., 2008), population densities of strains of fluorescent Pseudomonas spp. that are able to trigger ISR in wild-type Arabidopsis are much lower than their rhizosphere populations in the wild-type (Doornbos et al., 2009). This suggests cross communication between the plant and the ISR-eliciting bacteria, resulting in rewards for the plant, that becomes less susceptible to pathogen attack, and the bacteria, that establish higher population densities. Whereas in the absence of pathogens the state of induced resistance poses slight fitness costs on the plant, when pathogens are present the benefits of induced resistance greatly outweigh the costs (Van Hulten et al., 2006).

In Arabidopsis, a possible impact of the constitutive expression of induced resistance on bacterial community structure and diversity in the rhizosphere was studied (Hein et al., 2008). However, differences in bacterial diversity that were observed in this study could not be related to the expression of induced resistance. Application of defense inducing phytohormones salicylic acid and jasmonic acid did not result in major shifts in Arabidopsis rhizosphere bacterial communities (Doornbos et al., 2011). In the rhizospheres of Arabidopsis accessions RLD and WS-0, bacterial communities are distinct from those of Col-0 and five other accessions (Micallef et al., 2009). These data do suggest a possible impact of defense signaling on bacterial community structure, since RLD and WS-0 are relatively insensitive to ethylene and impaired in the expression of ISR compared to the other accessions (Ton et al., 1999, 2001).

Recent studies have provided exciting evidence that plants under attack recruit beneficial microbes in their rhizospheres, for example in Arabidopsis under attack of a bacterial pathogen (Rudrappa et al., 2008) or in pepper that is being fed upon by aphids (Lee et al., 2012). Such recruitment of beneficial microbes is also evident in monocultures of wheat, in which after an initial outbreak of take-all disease, disease suppressiveness caused by 2,4-diacetylphoroglucinol producing pseudomonads develops (Weller et al., 2002). 
Support for a cry for help hypothesis can also be found in a recent study by Mavrodi et al. (2012) in which 2,4-diacetylphloroglucinol producing pseudomonads were recruited in the rhizosphere of wheat under irrigated conditions and under dry conditions phenazine producing pseudomonads were recruited. G. graminis var. tritici, that is sensitive to 2,4-diacetylphloroglucinol, is the major pathogen under irrigated conditions, whereas $R$. solani, sensitive to phenazines, is the major pathogen under dry conditions.

\section{Concluding remarks}

Despite a century long history of rhizosphere research (Hartmann et al., 2008) we are still at the beginning of understanding the complex plant-microbe interactions in this dynamic environment (Bisseling et al., 2009). ISR is a powerful mode of action of biological control of plant diseases, but widespread practical applications in agriculture require a rigorous knowledge of the ISR eliciting microbes and their interactions with the rhizosphere microbiome. Positive interactions may occur, as for example antagonistic activity against plant pathogens by combinations of apparently non-antagonistic soil bacteria (De Boer et al., 2007). But also less expected negative effects in which harmless or even beneficial microbes assist incoming pathogens (Venturi and Passos de Silva, 2012). The complexity of the microbiome and the fact that most members are as yet uncultivated (Vartoukian et al., 2010) calls for new approaches. Exciting developments that will enable in depth studies of the functioning of the rhizosphere microbiome include the use of PhyloChips to study the composition of microbial communities (Hazen et al., 2010; Mendes et al., 2011), development of metatranscriptomics (Helbling et al., 2012; Mark et al., 2005), and metabolic profiling of root exudates (Van Dongen et al., 2009). Knowing the advantages and disadvantages of specific interactions will enable sensible applications to control diseases in a sustainable manner.

\section{References}

Alabouvette, C. 1999. Fusarium wilt suppressive soils: an example of disease suppressive soils. Australas. Plant Pathol. 28: $57-64$.

Anderson, I. C. and Cairney, J. W. G. 2004. Diversity and ecology of soil fungal communities: Increased understanding through the application of molecular techniques. Environ. Microbiol. 6:769-779.

Arumugam, M., Raes, J., Pelletier, E., Le Paslier, D., Yamada, T., Mende, D. R., Fernandes, G. R., Tap, J., Bruls, T., Batto, J.-M., Bertalan, M., Borruel, N., Casellas, F., Fernandez, L., Gautier, L., Hansen, T., Hattori, M., Hayashi, T., Kleerebezem, M.,
Kurokawa, K., Leclerc, M., Levenez, F., Manichanh, C., Nielsen, H. B., Nielsen, T., Pons, N., Poulain, J., Qin, J., Sicheritz-Ponten, T., Tims, S., Torrents, D., Ugarte, E., Zoetendal, E. G., Wang, J., Guarner, F., Pedersen, O., De Vos, W. M., Brunak, S., Doré, J., MetaHIT Consortium (additional members), Weissenbach, J., Ehrlich, S. D. and Bork, P. 2011. Enterotypes of the human gut microbiome. Nature 473:174180.

Audenaert, K., Pattery, T., Cornelis, P. and Höfte, M. 2002. Induction of systemic resistance to Botrytis cinerea in tomato by Pseudomonas aeruginosa 7NSK2: Role of salicylic acid, pyochelin, and pyocyanin. Mol. Plant-Microbe Interact. 15: 1147-1156.

Baker, K. F. and Cook, R. J. 1974. Biological Control of Plant Pathogens. W.H. Freeman, San Francisco.

Bakker, P. A. H. M., Pieterse, C. M. J. and Van Loon, L. C. 2007. Induced systemic resistance by fluorescent Pseudomonas spp. Phytopathology 97:239-243.

Bakker, P. A. H. M., Ran, L. X., Pieterse, C. M. J. and Van Loon, L. C. 2003. Understanding the involvement of induced systemic resistance in rhizobacteria-mediated biocontrol of plant diseases. Can. J. Plant Pathol. 25:5-9.

Berendsen, R. L., Pieterse, C. M. J. and Bakker P. A. H. M. 2012. The second genome and plant health. Trends Plant Sci. 17:478-486.

Bisseling, T., Dangl, J. L. and Schultze-Lefert, P. 2009. Next-generation communication. Science 324:691.

Bull, C. T., Weller, D. M. and Thomashow, L. S. 1991. Relationship between root colonization and suppression of Gaeumannomyces graminis var. tritici by Pseudomonas fluorescens strain 2-79. Phytopathology 81:954-959.

Crow, J. M. 2011. That Healthy gut feeling. Nature 480:S88-S89.

Da Rocha, A. B. and Hammerschmidt, R. 2005. History and perspectives on the use of disease resistance inducers in horticultural crops. HortTechology 15:518-529.

Derrien, M., Van Passel, M. W. J., Van de Bovenkamp, J. H. B., Schipper, R. G., De Vos, W. M. and Dekker, J. 2010. Mucinbacterial interactions in the human oral cavity and digestive tract. Gut. Microbes 1:254-268.

De Boer, W., Wagenaar, A-M., Klein Gunnewiek, P. J. A. and Van Veen, J. A. 2007. In vitro suppression of fungi caused by combinations of apparently non-antagonistic soil bacteria. FEMS Microbiol. Ecol. 59:177-185.

De Souza, J. T., Weller, D. M. and Raaijmakers, J. M. 2003. Frequency, diversity, and activity of 2,4-diacetylphloroglucinolproducing fluorescent Pseudomonas spp. in Dutch take-all decline soils. Phytopathology 93:54-63.

De Vleesschauwer, D., Cornelis, P. and Höfte, M. 2006. Redoxactive pyocyanin secreted by Pseudomonas aeruginosa 7NSK2 triggers systemic resistance to Magnaporte grisea but enhances Rhizoctonia solani susceptibility in rice. Mol. PlantMicrobe Interact. 19:1406-1419.

De Vleesschauwer, D., Djavaheri, M., Bakker, P. A. H. M. and Höfte, M. 2008. Pseudomonas fluorescens WCS374r-induced systemic resistance in rice against Magnaporthe oryzae is based on pseudobactin-mediated priming for a salicylic acid- 
repressible multifaceted defense response. Plant Physiol. 148: 1996-2012.

De Vleesschauwer, D. and Höfte, M. 2009. Rhizobacteria-induced systemic resistance. Adv. Bot. Res. 51: 223-281.

Diaz Heijtz, R., Wang, S., Anuar, F., Qian, Y., Bjorkholm, B., Samuelsson, A., Hibberd, M. L., Forssberg, H. and Pettersson, V. 2011. Normal gut microbiota modulates brain development and behavior. Proc. Natl. Acad. Sc. U.S.A. 108:3047-3052.

Doornbos, R. F., Geraats, B. P. J., Kuramae, E. E., Van Loon, L. C. and Bakker, P. A. H. M. 2011. Effects of jasmonic acid, ethylene, and salicylic acid signaling on the rhizosphere bacterial community of Arabidopsis thaliana. Mol. Plant-Microbe Interact. 24:395-407.

Doornbos, R. F., Van Loon, L. C. and Bakker, P. A. H. M. 2009. Beneficial Pseudomonas spp. have altered root colonization on Arabidopsis thaliana mutants affected in the expression of induced systemic resistance. In: Molecular tools for understanding and improving biocontrol. ed by B. Duffy, M. Maurhofer, C. Keel, C. Gessler, Y. Elad, and S. Kiewnick, IOBC/ wprs Bulletin 43:307-310.

Duijff, B. J., Recorbet, G., Bakker, P. A. H. M., Loper, J. E. and Lemanceau, P. 1999. Microbial antagonism at the root level is involved in the suppression of fusarium wilt by the combination of nonpathogenic Fusarium oxysporum Fo47 and Pseudomonas putida WCS358. Phytopathology 89:10731079.

Elsharkawy, M. M., Shimizu, M., Takahashi, H. and Hyakumachi, M. 2012. Induction of systemic resistance against Cucumber mosaic virus by Penicillium simplicissimum GP17-2 in Arabidopsis and tobacco. Plant Pathol. DOI: 10.1111/j.13653059.2011.02573.x

Fagundes, C. T., Amaral, F. A., Teixeira, A. L., Souza, D. G. and Teixeira, M. M. 2012. Adapting to environmental stresses: the role of the microbiota in controlling innate immunity and behavioral responses. Immunol. Rev. 245:250-264.

Fravel, D., Olivain, C. and Alabouvette, C. 2003. Fusarium oxysporum and its biocontrol. New Phytol. 157:493-502.

Gams, W. 2007. Biodiversity of soil-inhabiting fungi. Biodivers. Conserv. 16:69-72.

Glandorf, D. C. M., Peters, L. G. L., Van der Sluis, I., Bakker, P. A. H. M. and Schippers, B. 1993. Crop specificity of rhizosphere pseudomonads and the involvement of root agglutinins. Soil Biol. Biochem. 25:981-989.

Glandorf, D. C. M., Van der Sluis, I., Anderson, A. J., Bakker, P. A. H. M. and Schippers, B. 1994. Agglutination, adherence and root colonization by fluorescent pseudomonads. Appl. Environ. Microbiol. 60:1726-1733.

Grenham, S., Clarke, G., Cryan, J. F. and Dinan, T. G. 2011. Braingut-microbe communication in health and disease. Frontiers in Physiology 2: Article 94. DOI:10.3389/fphys.2011.00094.

Hartmann, A., Rothballer, M. and Schmid, M. 2008. Lorentz Hiltner, a pioneer in rhizosphere microbial ecology and soil bacteriology research. Plant Soil 312:7-14.

Hartmann, A., Schmid, M., Van Tuinen, D. and Berg, G. 2009. Plant-driven selection of microbes. Plant Soil 321:235-257.

Hazen, T. C., Dubinsky, E. A., DeSantis, T. Z., Andersen, G. L.,
Piceno, Y. M., Singh, N., Jansson, J. K., Probst, A., Borglin, S. E., Fortney, J. L., Stringfellow, W. T., Bill, M., Conrad, M. E., Tom, L. M., Chavarria, K. L., Alusi, T. R., Lamendella, R., Joyner, D. C., Spier, C., Baelum, J., Auer, M., Zemla, M. L., Chakraborty, R., Sonnenthal, E. L., D'haeseleer, P., Holman, H-Y. N., Osman, S., Lu, Z., Van Nostrand, J. D., Deng, Y., Zhou, J. and Mason, O. U. 2010. Deep-sea oil plume enriches indigenous oil degrading bacteria. Science 330:204-208.

Helbling, D. E., Ackermann, M., Fenner, K., Kohler, H-P. E. and Johnson, D. R. 2012. The activity level of a microbial community function can be predicted from its metatranscriptome. ISME J. 6:902-904.

Hein, J. W., Wolfe, G. V. and Blee, K. A. 2008. Comparison of rhizosphere bacterial communities in Arabidopsis thaliana mutants for systemic acquired resistance. Microb. Ecol. 55: 333-343.

Iavicoli, A., Boutet, E., Buchala, A. and Métraux, J. P. 2003. Induced systemic resistance in Arabidopsis thaliana in response to root inoculation with Pseudomonas fluorescens CHA0. Mol. Plant-Microbe Interact. 16:851-858.

Johnson, K. B. and DiLeone, J. A. 1999. Effect of antibiosis on antagonist dose-plant disease response relationships for the biological control of crown gall of tomato and cherry. Phytopathology 89:974-980.

Jourdan, E., Henry, G., Duby, F., Dommes, J., Barthelemy, J. P., Thonart, P. and Ongena, M. 2009. Insights into the defenserelated events occurring in plant cells following perception of surfactin-type lipopeptide from Bacillus subtilis. Mol. PlantMicrobe Interact. 22:456-468.

Katznelson, H., Lochhead, A. G. and Timonin, M. I. 1948. Soil microorganisms and the rhizosphere. Bot. Rev. 14:543-586.

Khan, M. S., Zaidi, A. and Wani, P. A. 2009. Role of phosphate solubilizing microorganisms in sustainable agriculture - a review. Agron. Sustain. Dev. 27:29-43.

Khoruts, A., Dicksved, J., Jansson, J. K. and Sadowsky, M. J. 2010. Changes in the composition of the human fecal microbiome after bacteriotherapy for recurrent Clostridium difficileassociated diarrhea. J. Clin. Gastroenterol. 44:354-360.

Kloepper, J. W., Ryu, C.-M. and Zhang, S. 2004. Induced systemic resistance and promotion of plant growth by Bacillus spp. Phytopathology 94:1259-1266.

Koike, N., Hyakumachi, M., Kageyama, K., Tsuyumu, S. and Doke, N. 2001. Induction of systemic resistance in cucumber against several diseases by plant growth-promoting fungi: lignification and superoxide generation. Eur. J. Plant Pathol. 108:187-196.

Kraiser, T., Gras, D. E., Gutierrez, A. G., Gonzalez, B. and Gutierrez, R. A. 2011. A holistic view of nitrogen acquisition in plants. J. Exp. Bot. 62:1455-1466.

Kyselkova, M., Kopecky, J., Frapolli, M., Defago, G., SagovaMareckova, M., Grundmann, G. L. and Moenne-Loccoz, Y. 2009. Comparison of rhizobacterial community composition in soil suppressive or conducive to tobacco black root rot disease. ISME J. 3:1127-1138.

Lee, B., Lee, S. and Ryu, M. R. 2012. Foliar aphid feeding recruits rhizosphere bacteria and primes plant immunity 
against pathogenic and non-pathogenic bacteria in pepper. Ann. Bot. 110:281-290.

Leeman, M., Van Pelt, J.A., Den Ouden, F. M., Heinsbroek, M., Bakker, P. A. H. M. and Schippers, B. 1995a. Induction of systemic resistance against fusarium wilt of radish by lipopolysaccharides of Pseudomonas fluorescens. Phytopathology 85: 1021-1027.

Leeman, M., Van Pelt, J. A., Hendrickx, M. J., Scheffer, R. J., Bakker, P. A. H. M. and Schippers, B. 1995b. Biocontrol of fusarium wilt of radish in commercial greenhouse trials by seed treatment with Pseudomonas fluorescens WCS374. Phytopathology 85:1301-1305.

Lemanceau, P., Corberand, T., Gardan, L., Latour, X., Laguerre, G., Boeufgras, J-M. and Alabouvette, C. 1995. Effect of two plant species, flax (Linum usitatissinum L.) and tomato (Lycopersicon esculentum Mill.) on the diversity of soilborne populations of fluorescent pseudomonads. Appl. Environ. Microbiol. 61:1004-1012.

Ling, N., Huang, Q., Guo, S. and Shen, Q. 2011. Paenibacillus polymyxa SQR-21 systemically affects root exudates of watermelon to decrease the conidial germination of Fusarium oxysporum f.sp. niveum. Plant Soil 341:485-493.

Mark, G. L., Dow, J. M., Kiely, P. D., Higgins, H., Haynes, J., Baysse, C., Abbas, A., Foley, T., Franks, A., Morrissey, J. and O'Gara, F. 2005. Transcriptome profiling of bacterial responses to root exudates identifies genes involved in microbe-plant interactions. Proc. Natl. Acad. Sc. USA 102: 17454-17459.

Maurhofer, M., Hase, C., Meuwly, P., Métraux, J. P. and Défago, G. 1994. Induction of systemic resistance of tobacco to tobacco necrosis virus by the root-colonizing Pseudomonas fluorescens strain CHA0: Influence of the gacA gene and of pyoverdine production. Phytopathology 84:39-146.

Mavrodi, O. V., Mavrodi, D. V., Parejko, J. A., Thomashow, L. S. and Weller, D. M. 2012. Irrigation differentially impacts populations of indigenous antibiotic-producing Pseudomonas spp. in the rhizosphere of wheat. Appl. Environ. Microbiol. 78: 3214-3220.

Mazurier, S., Corberand, T., Lemanceau, P. and Raaijmakers, J. M. 2009. Phenazine antibiotics produced by fluorescent pseudomonads contribute to natural soil suppressiveness to Fusarium wilt. ISME J. 3:977-991.

Mazzola, M. 2002. Mechanisms of natural soil suppressiveness to soilborne diseases. Anton. Leeuw. Int. J. G. 81:557-564.

Mendes, R., Kruijt, M., De Bruijn, I., Dekkers, E., Van der Voort, M., Schneider, J. H. M., Piceno, Y. M., DeSantis, T. Z., Andersen, G. L., Bakker, P. A. H. M. and Raaijmakers, J. M. 2011. Deciphering the rhizosphere microbiome for disease-suppressive bacteria. Science 332:1097-1100.

Meziane, H., Van der Sluis, I., Van Loon, L. C., Höfte, M. and Bakker, P. A. H. M. 2005. Determinants of Pseudomonas putida WCS358 involved in inducing systemic resistance in plants. Mol. Plant Pathol. 6:177-185.

Micallef, S. A., Shiaris, M. P. and Colon-Carmona, A. 2009. Influence of Arabidopsis thaliana accessions on rhizobacterial communities and natural variation in root exudates. J. Exp. Bot. 60:1729-1742.
Montesinos, E. and Bonaterra, A. 1996. Dose-response models in biological control of plant pathogens: an empirical verification. Phytopathology 86:464-472.

Ongena, M., Jourdan, E., Adam, A., Paquot, M., Brans, A., Joris, B., Arpigny, J.-L. and Thonart, P. 2007. Surfactin and fengycin lipopeptides of Bacillus subtilis as elicitors of induced systemic resistance in plants. Environ. Microbiol. 9:1084-1090.

Ongena, M., Jourdan, E., Schäfer, M., Kech, C., Budzikiewicz, H., Luxen, A. and Thonart, P. 2005. Isolation of an N-alkylated benzylamine derivative from Pseudomonas putida BTP1 as elicitor of induced systemic resistance in bean. Mol. PlantMicrobe Interact. 18:562-569.

Pozo, M. J., Verhage, A., García-Andrade, J., García, J. M. and Azcón-Aguilar, C. 2009. Priming plant defences against pathogens by arbuscular mycorrhizal fungi. In: Mycorrhizas: Functional processes and ecological impact, ed by C. AzcónAguilar, J. M. Barea, S. Gianinazzi, and V. Gianinazzi-Pearson, pp. 137-149. Springer-Verlag Heidelberg.

Press, C. M., Wilson, M., Tuzun, S. and Kloepper, J. W. 1997. salicylic acid produced by Serratia marcescens $90-166$ is not the primary determinant of induced systemic resistance in cucumber or tobacco. Mol. Plant-Microbe Interact. 10:761-768.

Raaijmakers, J. M., Leeman, M., Van Oorschot, M. M. P., Van der Sluis, I., Schippers, B. and Bakker, P. A. H. M. 1995. Doseresponse relationships in biological control of fusarium wilt of radish by Pseudomonas spp. Phytopathology 85:1075-1081.

Raaijmakers, J. M., Paulitz, T. C., Steinberg, C., Alabouvette, C. and Moënne-Loccoz, Y. 2009. The rhizosphere: a playground and battlefield for soilborne pathogens and beneficial microorganisms. Plant Soil 321:341-361.

Raaijmakers, J. M., Vlami, M. and De Souza, T. J. 2002. Antibiotic production by bacterial biocontrol agents. Anton. Leeuw. Int. J. G. 81:537-547.

Raaijmakers, J. M. and Weller, D. M. 1998. Natural plant protection by 2,4-diacetylphloroglucinol-producing Pseudomonas spp. in take-all decline soils. Mol. Plant-Microbe Interact. 11: 144-152.

Ran, L. X., Li, Z. N., Wu, G. J., Van Loon, L. C. and Bakker, P. A. H. M. 2005. Induction of systemic resistance against bacterial wilt in Eucalyptus urophylla by fluorescent Pseudomonas spp. Eur. J. Plant Pathol. 113:59-70.

Reglinski, T. and Walters, D. 2009. Induced resistance for plant disease control. In: Disease Control in Crops, ed by D. Walters, pp. 62-92. Wiley-Blackwell, Oxford UK.

Rosenzweig, N., Tiedje, J. M., Quensen, J. F., III, Meng, Q. and Hao, J. J. 2012. Microbial communities associated with potato common scab-suppressive soil determined by pyrosequencing analyses. Plant Dis. 96:718-725.

Rudrappa, T., Czymmek, K. J., Paré, P. W. and Bais, H. P. 2008. Root-secreted malic acid recruits beneficial soil bacteria. Plant Physiol. 148:1547-1556.

Ryu, C. M., Farag, M. A., Hu, C. H., Reddy, M. S., Kloepper, J. W. and Paré, P. W. 2004. Bacterial volatiles induce systemic resistance in Arabidopsis. Plant Physiol. 134:1017-1026.

Sanguin, H., Sarniguet, A., Gazengel, K., Moenne-Loccoz, Y. and Grundmann, G. L. 2009. Rhizosphere bacterial communities 
associated with disease suppressiveness stages of take-all decline in wheat monoculture. New Phytol. 184:694-707.

Schreiner, K., Hagn, A., Kyselkova, M., Moenne-Loccoz, Y., Welzl, G., Munch, J. C. and Schloter, M. 2010. Comparison of barley succession and take-all disease as environmental factors shaping the rhizobacterial community during take-all decline. Appl. Environ. Microbiol. 76:4703-4712.

Schuhegger, R., Ihring, A., Gantner, S., Bahnweg, G., Knappe, C., Vogg, G., Hutzler, P., Schmid, M., Van Breusegem, F., Eberl, L., Hartmann, A. and Langebartels, C. 2006. Induction of systemic resistance in tomato by $\mathrm{N}$-acyl-L-homoserine lactoneproducing rhizosphere bacteria. Plant Cell Environm. 29: 909-918.

Segarra, G., Van der Ent, S., Trillas, I. and Pieterse, C. M. J. 2009. MYB72, a node of convergence in induced systemic resistance triggered by a fungal and a bacterial beneficial microbe. Plant Biology 11:90-96.

Shoresh, M., Harman, G. E. and Mastouri, F. 2010. Induced systemic resistance and plant responses to fungal biocontrol agents. Annu. Rev. Phytopathol. 48:21-43.

Sultana, S., Hossian, Md. M., Kubota, M. and Hyakumachi, M. 2009. Induction of systemic resistance in Arabidopsis thaliana in response to a culture filtrate from a plant growth-promoting fungus, Phoma sp. GS8-3. Plant Biology 11:97-104.

Thamer, S., Schädler, M., Bonte, D. and Ballhorn, D. J. 2011. Dual benefit from a belowground symbiosis: nitrogen fixing rhizobia promote growth and defense against a specialist herbivore in a cyanogenic plant. Plant Soil 341:209-219.

Ton, J., Davison, S., Van Wees, S. C. M., Van Loon, L. C. and Pieterse, C. M. J. 2001. The Arabidopsis ISR1 locus controlling rhizobacteria-mediated induced systemic resistance is involved in ethylene signaling. Plant Physiol. 125:652-661.

Ton, J., Pieterse, C. M. J. and Van Loon, L. C. 1999. Identification of a locus in Arabidopsis controlling both the expression of rhizobacteria-mediated induced systemic resistance (ISR) and basal resistance against Pseudomonas syringae pv. tomato. Mol. Plant-Microbe Interact. 12:911-918.

Tran, H., Ficke, A., Asiimwe, T., Höfte, M. and Raaijmakers, J. M. 2007. Role of the cyclic lipopeptide massetolide A in biological control of Phytophthora infestans and in colonization of tomato plants by Pseudomonas fluorescens. New Phytol. 175:731-742.

Turnbaugh, P. J., Hamady, M., Yatsunenko, T., Cantarel, B. L., Duncan, A., Ley, R. E., Sogin, M. L., Jones, W. J., Roe, B. A., Affourtit, J. P., Egholm, M., Henrissat, B., Heath, A. C., Knoght, R. and Gordon, J. I. 2009. A core gut microbiome in obese and lean twins. Nature 457:480-486.

Turnbaugh, P. J., Ley, R. E., Mahowald, M. A., Magrini, V., Mardis, E. R. and Gordon, J. I. 2006. An obesity-associated gut microbiome with increased capacity for energy harvest. Nature 444:1027-1031.

Van der Ent, S., Verhagen, B. W. M., Van Doorn, R., Bakker, D., Verlaan, M. G., Pel, M. J. C., Joosten, R. G., Proveniers, M. C. G., Van Loon, L. C., Ton, J. and Pieterse, C. M. J. 2008. MYB72 is required in early signaling steps of rhizobacteriainduced systemic resistance in Arabidopsis. Plant Physiol.
146:1293-1304.

Van Dongen, J. T., Frohlich, A., Ramirez-Aguilar, S. J., Schauer, N., Fernie, A. R., Erban, A., Kopka, J., Clark, J., Langer, A. and Geigenberger, P. 2009. Transcript and metabolite profiling of the adaptive response to mild decreases in oxygen concentration in the roots of Arabidopsis plants. Annals Bot. 103: 269-280.

Van der Heijden, M. G. A., Bradgett, R. D. and Van Straalen, N. M. 2008. The unseen majority: soil microbes as drivers of plant diversity and productivity in terrestrial ecosystems. Ecology Letters 11:296-310.

Van der Heijden, M. G. A., Streitwolf-Engel, R., Riedl, R., Siegrist, S., Neudecker, A., Ineichen, K., Boller, T., Wiemken, A. and Sanders, I. R. 2006. The mycorrhizal contribution to plant productivity, plant nutrition and soil structure in experimental grassland. New Phytol. 172:739-752.

Van Hulten, M., Pelser, M., Van Loon, L. C., Pieterse, C. M. J. and Ton, J. 2006. Costs and benefits of priming for defense in Arabidopsis. Proc. Natl. Acad. Sci. USA 103:5602-5607.

Van Loon, L. C. and Bakker, P. A. H. M. 2005. Induced systemic resistance as a mechanism of disease suppression by rhizobacteria. In: PGPR: Biocontrol and biofertilization, ed by Z.A. Siddiqui, pp. 39-66. Springer, Dordrecht, the Netherlands.

Van Loon, L. C., Bakker, P. A. H. M. and Pieterse, C. M. J. 1998. Systemic resistance induced by rhizosphere bacteria. Аnпи. Rev. Phytopathol. 36:453-483.

Van Peer, R. and Schippers, B. 1992. Lipopolysaccharides of plant-growth promoting Pseudomonas sp. strain WCS417r induce resistance in carnation to Fusarium wilt. Neth. J. Plant Pathol. 98:129-139.

Van Peer, R., Niemann, G. J. and Schippers, B. 1991. Induced resistance and phytoalexin accumulation in biological control of fusarium wilt of carnation by Pseudomonas sp. strain WCS417r. Phytopathology 81:728-734.

Van Pelt, J. A., Van der Sluis, I., Pieterse, C. M. J. and Bakker, P. A. H. M. 2008. Induced systemic resistance Bioassays in Arabidopsis thaliana. In: Prospects and applications for plantassociated microbes A laboratory manual Part A: Bacteria, ed by S. Sorvari and A. M. Pirttila, pp. 113-118. BBI Piikkio, Finland.

Vartoukian, S. R., Palmer, R. M. and Wade, W .G. 2010. Strategies for culture of 'unculturable' bacteria. FEMS Microbiol. Lett. 309:1-7.

Venturi, V. and Passos da Silva, D. 2012. Incoming pathogens team up with harmless "resident" bacteria. Trends Microbiol. 20:160-164.

Wei, G., Kloepper, J. W. and Tuzun, S. 1991. Induction of systemic resistance of cucumber to Colletotrichum orbiculare by select strains of plant growth-promoting rhizobacteria. Phytopathology 81:1508-1512.

Wei, G., Kloepper, J. W. and Tuzun, S. 1996. Induced systemic resistance to cucumber diseases and increased plant growth by plant growth-promoting rhizobacteria under field conditions. Phytopathology 86:221-224.

Weller, D. M. 2007. Pseudomonas biocontrol agents of soilborne pathogens: looking back over 30 years. Phytopathology 97: 
$250-256$.

Weller, D. M., Mavrodi, D. V., Van Pelt, J. A., Pieterse, C. M. J., Van Loon, L. C. and Bakker, P. A. H. M. 2012. Induced systemic resistance (ISR) in Arabidopsis thaliana against Pseudomonas syringae pv. tomato by 2,4-diacetylphloroglucinol-producing Pseudomonas fluorescens. Phytopathology 102:403-412.

Weller, D. M., Raaijmakers, J. M., McSpadden Gardener, B. B. and Thomashow, L. S. 2002. Microbia populations responsible for specific soil suppressiveness to plant pathogens. Аnпи. Rev. Phytopathol. 40:309-348.
Williams, B. L., Hornig, M., Parekh, T. and Lipkin, W. I. 2012. Application of novel PCR-based methods for detection, quantitation, and phylogenetic characterization of Sutterella species in intestinal biopsy samples from children with autism and gastrointestinal disturbances. mBio 3:e0261-11.

Yang, J., Kloepper, J. W. and Ryu, C.-M. 2008. Rhizosphere bacteria help plants tolerate abiotic stress. Trends Plant Sci. 14:14.

Zamioudis, C. and Pieterse, C. M. J. 2012. Modulation of host immunity by beneficial microbes. Mol. Plant-Microbe Interact. 25:139-150. 